\title{
DNA Replication in Relation to S Phase Duration in Six Angiosperm Annual Species
}

\author{
M. J. Olszewska ${ }^{1}$, J. Maszewski ${ }^{2}$ and A. Bilecka \\ ${ }^{1}$ Department of Plant Cytology and Cytochemistry and ${ }^{2}$ Laboratory of \\ Cytophysiology, Institute of Physiology and Cytology, University \\ of Lodz, Banacha 12/16, 90-237 Lodz, Poland
}

Accepted May 12, 1989

Since the discovery that $\mathrm{S}$ phase duration (Ts) in diploid higher plants can be regarded as a function of nuclear DNA content (Van't Hof 1965), this problem has gained much attention. Introduction of fiber autoradiography enabled an insight into the organization of nuclear DNA replication at the level of replicons. Evidence based on this technique proved that $T s$ is determined by a minimal number of replicons that function sequentially during S phase (Van't Hof and Bjerknes 1981, Francis et al. 1985, Kidd et al. 1987).

A number of investigated species, however, do not follow the relations between $2 \mathrm{C}$ DNA value and Ts (Olszewska et al. 1989). The present work was focused on replicon arrangement and Ts in six diploid species in which no correlation between 2C DNA value and Ts was found.

\section{Material and methods}

Plant species are listed in Table 1 according to increasing Ts. The experiments were carried out on the same samples of seeds which were used for investigations aimed at determination of Ts values (Olszewska et al. 1989).

Fiber autoradiograms were made according to the procedure described by Marciniak and Maszewski (1989). After $2 \times 10^{-8} \mathrm{M}$ FUdR pretreatment, sequential "warm pulse-hot pulse chase" labelling ( ${ }^{3} \mathrm{H}-6$-thymidine, act. spec. $960 \mathrm{GBq} / \mathrm{mM}, 250$ and $25 \mu \mathrm{Ci} / \mathrm{ml}$, respectively) of aseptically germinated 3-day old seedlings ( $2 \mathrm{~mm}$ long apical root segents) was followed by nuclear chromatin dispersion and spreading in trypsin and sarcosyl-containing EDTA mixture. Dried preparations were coated with Ilford $\mathrm{K} 2$ emulsion and exposed at $4^{\circ} \mathrm{C}$ for 2 to 4 months. Labelled DNA tracks were measured on microphotographs made through a $40 \times$ flat-field objective. Origin-to-origin distances were scored (1052 to 1330 measurements) from fibers with three or more sequentially aligned pairs of symmetrical tandem arrays (Fig. 1). The time needed to replicate an average, single replicon (Rs) was calculated by dividing the mean replicon size by twice the average replicon fork rate, obtained as track length ( 304 to 1034 measurements) divided by the incubation time.

\section{Results}

Data obtained from DNA fiber autoradiographic labelling patterns and genome characteristics for 6 analyzed species are given in Table 1. Replicons ranged from 20 to $125 \mu \mathrm{m}$ in size (Fig. 1 a-d, Fig. 2) and fork rate varied from 10.2 to $39.6 \mu \mathrm{m} / \mathrm{h}$. In some fibers asynchronous replication patterns, i. e. showing different arrangement of grains were observed (Fig. $1 \mathrm{e}$ ).

As evidenced in Fig. 3 a, no linear correlation $(r=-0.42)$ can be established between $2 \mathrm{C}$ DNA level and $\mathrm{Rs} / \mathrm{Ts}$ ratio, while a strong positive correlation $(r=0.97, p=0.001)$ is to 
be found between Ts and Ts/Rs values (Fig. 3 b), where Ts/Rs ratio estimates the minimal number of replicon families that function sequentially during $S$ phase (Van't Hof and Bjerknes 1981). Negative correlation $(r=-0.78, p=0.05)$ exists between $2 C$ DNA content and rate of fork movement (Fig. $3 \mathrm{c}$ ). Comparison of Ts and both replicon sizes and the rate of fork movement reveals no correlation, bringing $r$ values of 0.49 and -0.02 , respectively.

\section{Discussion}

Despite the fact that data presented in our study for replicon sizes seem overestimated as compared with those collected by Francis et al. (1985), taking into account the relationship between replicon size and duration of ${ }^{3} \mathrm{H}$-thymidine pulse (Kidd et al. 1987), the obtained values cover the ranges between 15-50 $\mu \mathrm{m}$ which are considered as typical (Waterborg and Shall 1985). Moreover, the differences between Rs/Ts ratios among the same species studied

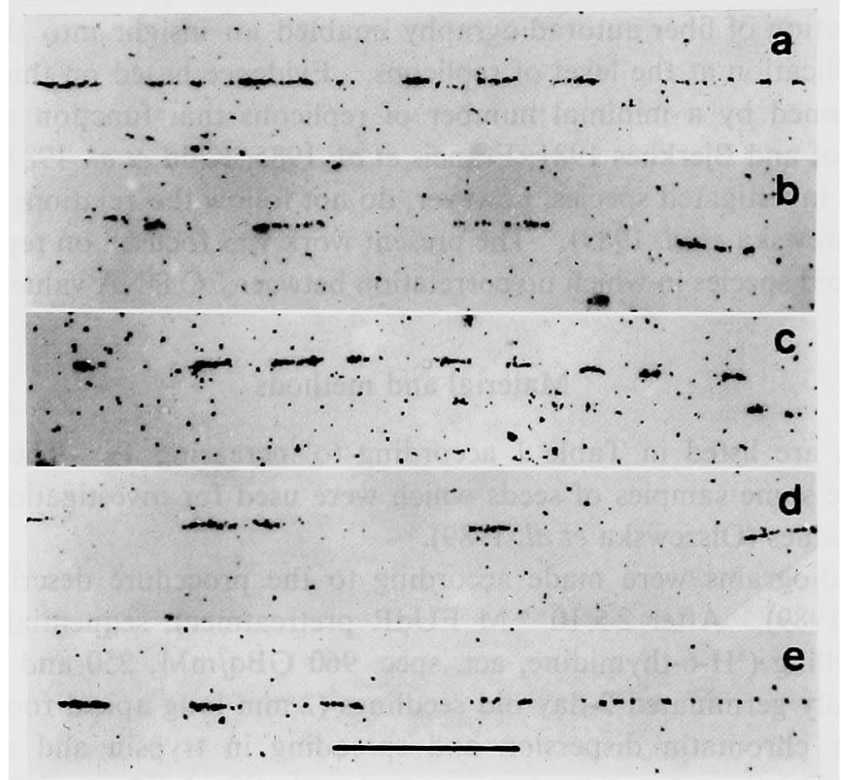

Fig. 1. Different labelling patterns of DNA replicating fibres. a-d, Helianthus annuus. e, Pisum sativum. Strongly and weakly labelled tracks $(a, b)$. Different sizes of replicons (a-d). Intrafibrillar asynchrony (e). $B a r=50 \mu \mathrm{m}$.

earlier (Francis et al. 1985) and those calculated in the present study are similar, the values, however, being not identical (Fig. 3 a).

In the previous studies of Francis et al. (1985) and Kidd et al. (1987), and in our work, no correlations could be found between DNA C values and replicon sizes. Negative correlation between genome size and Rs/Ts ratios (Francis et al. 1985, Kidd et al. 1987) was not found in our material. Contrasting results were obtained, as well, for correlation estimates of DNA $C$ values plotted against the rates of fork movement. Both Francis et al. (1985) and Kidd et al. (1987) found lack of correlation, while our results established a weak correlation with the negative value (Fig. $3 \mathrm{c}$ ). The strong correlation found between $\mathrm{Ts}$ and $\mathrm{Ts} / \mathrm{Rs}$ ratio (Fig. $3 \mathrm{~b}$ ) indicates thus that the differences in Ts may reflect changes in temporal pattern of activation of replication origins.

The Ts value seems to depend upon percentage of repetitive sequences within the genome (Table 1). Kidd et al. (1987) suggested that "Perhaps the increase in the amount of repeti- 
tive sequences per basic genome is particularly related to asynchrony of replication activation". This idea is a consequence of Flavell's (1980) hypothesis that chromatin condensation determines in part the availability of chromosomal sites applicable as replicon origins. There exists a close relationship between the proportion of repetitive sequences and the amount of chromatin in a condensed state (Nagl et al. 1983).
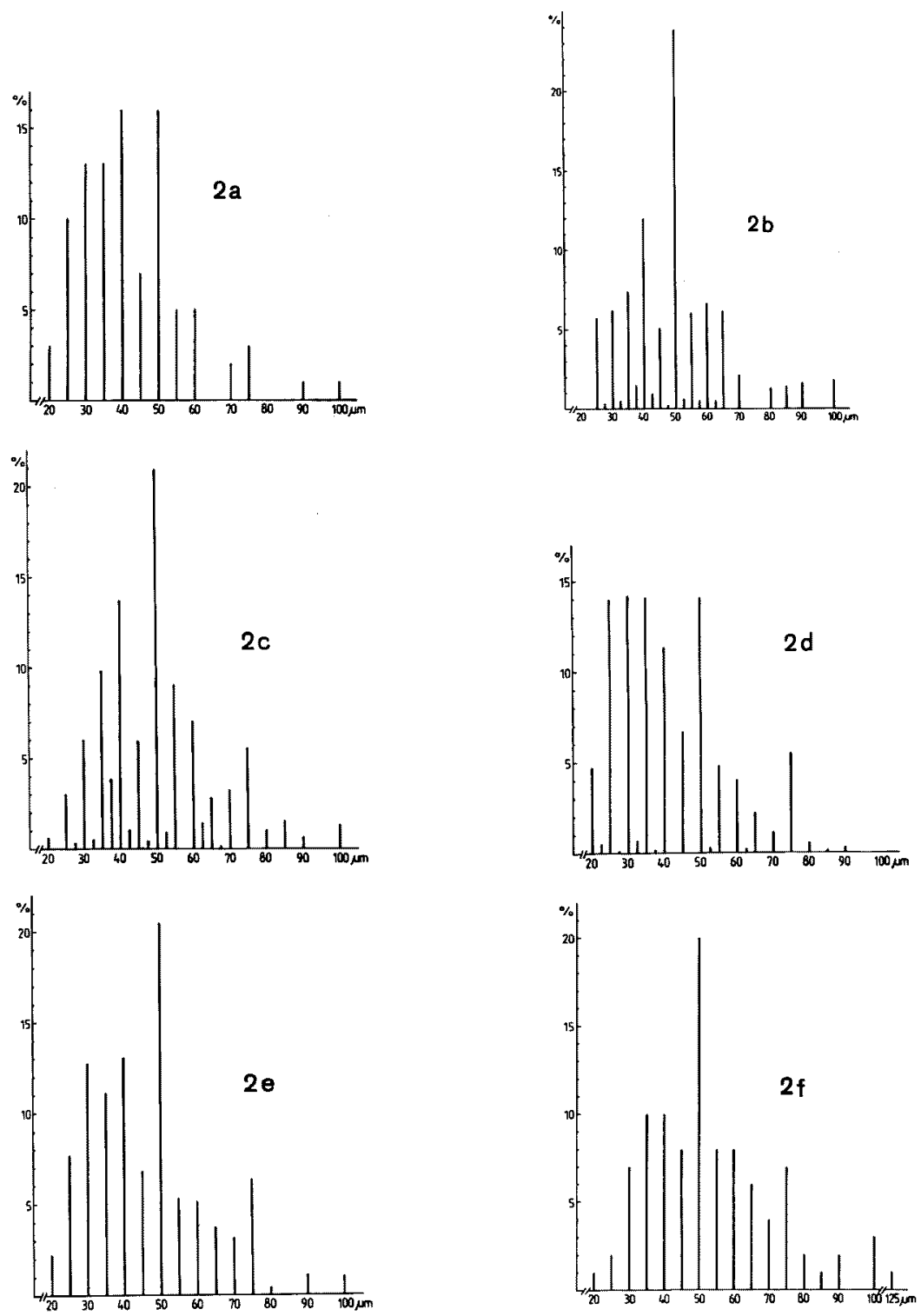

Fig. 2. Frequency distribution of replicon sizes. a, Glycine max. b, Helianthus annuus. c, Vicia sativa. d, Lathyrus odoratus. e, Pisum sativum. f, Zea mays.

In conclusion, it seems reasonable to assume that the negative correlation between $2 \mathrm{C}$ value and replication fork movement reflects one of the mechanisms involved in the regulation of $S$ phase duration. Moreover, the Ts may be viewed as a result of the minimal replicon families that function sequentially during $S$ phase. 


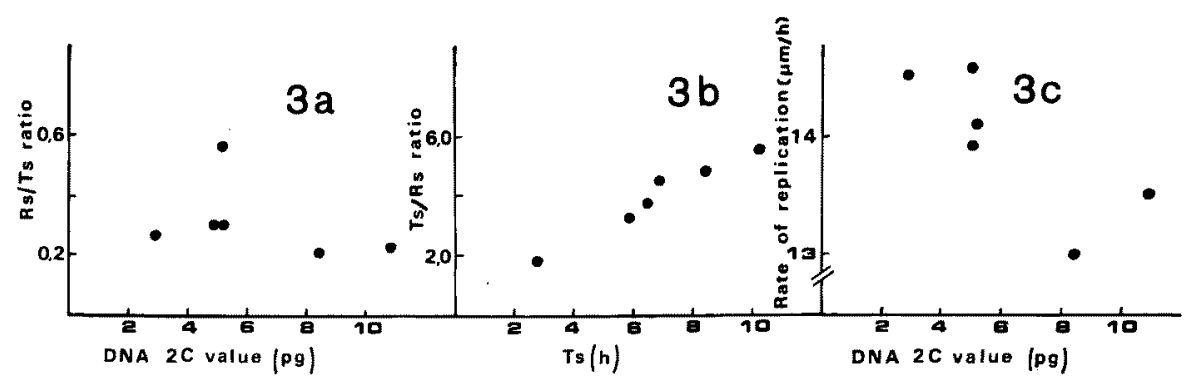

Fig. 3. a, lack of correlation between 2C DNA and Rs/Ts values. b, positive correlation between $T s$ and $T s / R s$ values. c, negative correlation between $2 C$ DNA and rate of replication fork movement.

Table 1. Characteristics of DNA and DNA replication in species under study

\begin{tabular}{|c|c|c|c|c|c|c|c|}
\hline Species & Ts, $h^{\mathfrak{l})}$ & $\underset{\text { pg }}{2 \mathrm{C} \text { DNA, }}$ & $\begin{array}{l}\% \text { of re- } \\
\text { petitive } \\
\text { sequences }\end{array}$ & $\begin{array}{l}\text { Average } \\
\text { replicon } \\
\text { size, } \mu \mathrm{m}\end{array}$ & $\begin{array}{l}\text { Rate of fork } \\
\text { movement, } \\
\mu \mathrm{m} / \mathrm{h}\end{array}$ & Rs & Rs/Ts \\
\hline Glycine max & 2.8 & $5.1^{12}$ & & $\begin{array}{r}43.9 \\
\pm 0.6\end{array}$ & 14.1 & 1.56 & 1.79 \\
\hline $\begin{array}{l}\text { Helianthus } \\
\text { annuus cv. } \\
\text { Jadalny }\end{array}$ & 5.9 & $5.0^{2)}$ & $69.0^{32}$ & $\begin{array}{r}51.1 \\
\pm 0.4\end{array}$ & 13.9 & 1.84 & 3.21 \\
\hline $\begin{array}{l}\text { Vicia sativa } \\
\text { Winter cv. }\end{array}$ & 6.4 & $2.9^{1)}$ & & $\begin{array}{r}49.6 \\
+0.5\end{array}$ & 14.5 & 1.71 & 3.74 \\
\hline $\begin{array}{l}\text { Lathyrus } \\
\quad \text { odoratus }\end{array}$ & 6.8 & $10.9^{2)}$ & $70.1^{4)}$ & $\begin{array}{r}41.2 \\
\pm 0.4\end{array}$ & 13.5 & 1.52 & 4.47 \\
\hline $\begin{array}{l}\text { Pisum sativum } \\
\text { cv. Paloma }\end{array}$ & 8.5 & $8.4^{1)}$ & $75.0^{3)}$ & $\begin{array}{r}46.1 \\
\pm 0.4\end{array}$ & 13.0 & 1.77 & 4.80 \\
\hline $\begin{array}{l}\text { Zea mays } \\
\mathrm{cv} \text {. Golden } \\
\text { Bentham }\end{array}$ & 10.2 & $5.0^{1)}$ & 78.0 & $\begin{array}{r}53.9 \\
\pm 0.6\end{array}$ & 14.6 & 1.84 & 5.54 \\
\hline
\end{tabular}

1) Olszewska et al. (1989).

2) Olszewska and Osiecka (1983).

3) Flavell et al. (1974).

4) Nagl et al. (1983).

\section{Summary}

Using fiber autoradiography, replicon sizes and DNA replication fork rates were studied in 6 diploid angiosperm annual species with different 2C DNA values and S phase durations (Ts). The only correlations were found between Ts and Rs/Ts ratios (positive correlation, $\mathrm{p}=0.001$ ) and between $2 \mathrm{C}$ DNA content and the rate of fork movement (negative correlation, $p=0.05$ ). The observations raise the possibility of a connection between the mechanisms involved in DNA chain elongation and the amount of repetitive sequences and between Ts and the functional arrangements of replicons.

\section{Acknowledgements}

This work was supported by the Polish Academy of Sciences within the project 04. 01 . 05. 07 .

\section{References}

Flavell, R. 1980. The molecular characterization and organization of plant chromosomal DNA sequences. Ann. Rev. Plant Physiol. 31: 569-596. 
-, B., Bennett, M. D. and Smith, J. B. 1974. Genome size and the proportion of repeated nucleotide sequences in plants. Biochem. Gen. 12: 257-269.

Francis, D., Kidd, A. D. and Bennett, M. D. 1985. DNA replication in relation to DNA C values. In: The Cell Division Cycle in Plants (J. A. Bryant and D. Francis, eds): 61-82. Cambridge University Press, Cambridge, London, New York, New Rochelle, Melbourne, Sydney.

Kidd, A. D., Francis, D. and Bennett, M. D. 1987. Replicon size, mean rate of DNA replication and the duration of the cell cycle and its component phases in eight monocotyledonous species of contrasting DNA C values. Ann. Bot. 59: 603-609.

Marciniak, K. and Maszewski, J. 1989. Replicon size and the rate of DNA synthesis during root cell differentiation in Vicia faba subsp. minor and major. Biol. Zent. Bl. 108 : 241-248.

Nagl, W., Jeanjour, M., Kling, H., Kuhner, S., Michels, I., Muller, T. and Stein, B. 1983. Genome and chromatin organization in higher plants. Biol. Zent. BI. 102: 129-148.

Olszewska, M. J., Bilecka, A., Kuran, H., Marciniak, K. and Jakubinski, J. 1989. Dry mass and protein increase during interphase as a possible factor regulating the cell cycle duration. Caryologia, in press.

- and Osiecka, R. 1983. The relationship between 2C DNA content, life cycle type, systematic position and the dynamics of DNA endoreplication in parenchyma nuclei during growth and differentiation of roots in some dicotyledonous herbaceous species. Biochem. Physiol. Pflanzen 178: 578-599.

Van't Hof, J. 1965. Relationship between mitotic cycle duration, $\mathbf{S}$ period duration and the average rate of DNA synthesis in the root meristem cells of several plants. Exp. Cell Res. 39: 48-56.

- and Bjerknes, C. A. 1981. Similar replicon properties of higher plant cells with different S-periods and genome sizes. Exp. Cell Res. 136: 461-465.

Waterborg, J. H. and Shall, S. 1985. The organization of replicons. In: The Cell Division Cycle in Plants (J. A. Bryant and D. Francis, eds): 15-35. Cambridge University Press, Cambridge, London, New York, New Rochelle, Melbourne, Sydney. 